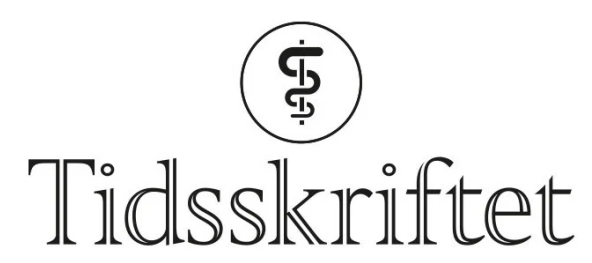

DEN NORSKE LEGEFORENING

\title{
Vaksiner til verden
}

\author{
KOMMENTAR
}

ANNE KARIN RIME

anne-karin.rime@legeforeningen.no

Anne Karin Rime er president i Legeforeningen.

\section{MARIT HALONEN CHRISTIANSEN}

Ingen av forfatterne har oppgitt noen interessekonflikter.

I Tidsskriftet nr. 18/2021 skriver Elin Hoffmann Dahl og Ida Tveter (1) om at våre kollegaer i utlandet står uvaksinerte i frontlinjen.

Vi er enige i situasjonsbeskrivelsen når det gjelder fordeling av vaksiner i verden. Det er urettferdig og irrasjonelt at de rike landene i verden har lagt beslag på en så stor andel av vaksineproduksjonen det første året. Vi er også enige i at dette bør vektlegges i større grad i de strategier som legges i nasjonale vaksineprogram. Satt på spissen: gir det egentlig mening å snakke om strengt nasjonalt avgrensede vaksineprogram i en pandemi?

I skrivende stund endrer pandemibildet seg fra time til time. Legeforeningen mener FHI i sine fremskrivninger må ta med situasjonen som utvikler seg globalt. Norge må oppfordre og bidra til deling av vaksiner, og likeprioritering av lav-, mellom- og høyinntektsland når det kommer til leveranser av vaksiner. Legeforeningen formidler dette gjennom sine kanaler, blant annet World Medical Association.

Vi ber Norge som nasjon gjøre det samme. Legeforeningens råd til myndighetene er å i større grad ta ansvar for å framskaffe vaksinedoser, og sikre leveringskjeder til land der dette er en utfordring. Vi mener verdens regjeringer har et soleklart ansvar for å løse dette på en bedre måte enn det som har vært demonstrert til nå.

Legeforeningen tar ikke stilling til hvordan målet bør nås, men er klar på at ansvaret for å nå målet påligger verdens regjeringer - deriblant den norske.

\section{LITTERATUR}

1. Dahl EH, Tveter I. Våre kollegaer står uvaksinerte i frontlinjen. Tidsskr Nor Legeforen 2021; 141. doi: 10.4045/tidsskr.21.0810. [PubMed][CrossRef] 
Publisert: 31. januar 2022. Tidsskr Nor Legeforen. DOI: 10.4045/tidsskr.22.0020

(C) Tidsskrift for Den norske legeforening 2023. Lastet ned fra tidsskriftet.no 26. april 2023. 